\title{
Experimental assessment of oyster transfers as a vector for macroalgal introductions
}

\author{
Frédéric Mineur ${ }^{1 *}$, Thomas Belsher ${ }^{2}$, Mark P. Johnson ${ }^{1}$, Christine A. Maggs $^{1} \&$ Marc Verlaque $^{3}$
}

${ }^{1}$ School of Biological Sciences, Queen's University of Belfast, Belfast BT9 7BL, UK

${ }^{2}$ IFREMER Sète, Avenue Jean Monnet, BP 171-34203 Sète cedex, France

${ }^{3}$ UMR 6540 DIMAR, COM, Université de la Méditerranée, 13288 Marseille cedex 9, France

*Corresponding author: Frédéric Mineur (e-mail: f.mineur@qub.ac.uk)

\begin{abstract}
:
Introduction of non-indigenous species can alter marine communities and ecosystems. In shellfish farming, transfer of livestock, especially oysters, is a common practice and potentially constitutes a pathway for non-indigenous introductions. Many species of seaweeds are believed to have been accidentally introduced in association with these transfers, but there is little direct evidence.

We experimentally simulated the transfer of oysters from the Thau Lagoon (France). These transfers involved increasing periods of aerial emersion and additional brine and hot water treatments. The brine and hot water treatments were evaluated as a means of reducing the probability of algal introductions with oyster transfers. Shells were cultured for 40 days in experimental tanks to identify the macroalgae likely to be introduced with any oyster transfer.
\end{abstract}

A total of 57 macroalgal taxa, including 16 taxa not indigenous to the Thau Lagoon, were recorded across all treatments and experiments. The abundance of some species increased in several cases following aerial emersion. Elimination treatments (immersion in brine or hot water) significantly reduced algal diversity, with hot water treatments resulting in no species or only tubular Ulva spp. present.

The results support the hypothesis that oyster transfers are effective as primary and secondary vectors of macroalgal introductions. Relatively simple changes to the transfer practice (particularly hot water treatments) are suggested as a means of reducing the risk of non-indigenous algal introductions.

Keywords: Biological invasions; Crassostrea gigas; Shells; Thau Lagoon; Marine macrophytes; Transport; Elimination treatments 


\section{Introduction}

The introduction of non-indigenous species is an important factor causing alterations of communities and ecosystems (Gurevitch and Padilla, 2004). In some marine environments, introductions of invertebrates or parasites have led to the decline of native species (e.g. Grosholz et al., 2000). Seaweed (macroalgal) invasions also profoundly modify recipient communities (Piazzi and Cinelli, 2003; Strong et al., 2006).

By definition, the first step leading to a biological invasion is the transportation of the species from the donor community, which involves a vector (Carlton et al., 1996; Kolar and Lodge, 2001; Lockwood et al., 2005). Among the vectors involved in macroalgal introductions, aquaculture, particularly shellfish transfers, is considered to be the most important (Ribera Siguan, 2002; Wallentinus, 2002).

Transfers of shellfish, especially oysters, date back to the Roman period (Héral, 1990). The modern European oyster industry depended for decades on the native oyster Ostrea edulis Linnaeus and a strain of Crassostrea gigas (Thunberg), called the Portuguese oyster, which was probably introduced from Taiwan in the 16th century (O'Foighil et al., 1997; Boudry et al., 1998). In 1970, oyster farming in Europe was facing a collapse due to disease, and required massive imports of $C$. gigas from the Pacific. To sustain future production, both adult oysters and spat were imported from British Columbia and Japan, respectively. Around 10,000 tons (i.e. more than 5 billion small oysters) were imported between 1971 and 1977 (Gruet et al., 1976; Grizel and Héral, 1991). Nowadays, such imports have been considerably reduced as a consequence of the self-sustaining spat production of $C$. gigas in Europe. The European Union now restricts imports of oysters to those from a few countries around the Mediterranean (Croatia, Morocco, Tunisia, Turkey) and from the USA, Canada and New Zealand (Anonymous, 2003b, 2005).

European oyster farming, as practised in France, involves continuous transfers of livestock between shellfish culture sites to ensure optimal growth conditions for each part of the rearing cycle (Goulletquer and Le Moine, 2002; Girard et al., 2005). In C. gigas, the natural recruitment of larvae can be irregular (Le Borgne et al., 1973) and economically sustainable exploitation of populations is only possible in some areas such as SW France (Grizel and Héral, 1991; Minchin, 1996). Spat production in hatcheries is an alternative (Utting and Spencer, 1992; Robert and Gerard, 1999). Natural and hatchery reared spat may both be exported to other sites that are suitable for the growth of the livestock. An optional further stage of the culture process is "greening", a method used around the Charentais sounds and Marennes-Oleron Bay, whereby oysters are immersed in saline ponds and fed naturally or artificially with the diatom Haslea ostrearia (Gaillon) Simonsen to give the flesh a green colour and a particular taste (Turpin et al., 2001; Robert et al., 2002). The final step in oyster culture is a temporary immersion in sterilized seawater for sanitary purposes (depuration) before oysters are sold for human consumption. During the cultivation cycle oysters may therefore be transferred several times (Fig. 1). A typical example would be from a spat-producing area on the French Atlantic, to a Mediterranean site such as the Thau lagoon to be grown in suspension, and back to the Atlantic "greening" ponds of the Marennes-Oléron area, before marketing. Such transfers are permitted within the European Community and there is no obligation to report them. Transport restrictions are only applied if the livestock have been exposed to parasitic diseases (Anonymous, 1991, 2003a, b, 2005).

Over the last few decades, many arrivals of exotic seaweeds (e.g. Sargassum muticum, Undaria pinnatifida, Dasysiphonia sp.) have been recorded in the immediate surroundings of oyster farming areas (e.g. Gruet, 1976; Anonymous, 1980, 1982; Perez et al., 1981; Verlaque, 1981, 2002; Riouall, 1985; Cabioc'h and Magne, 1987; Stegenga, 1997; Verlaque et al., 2002, 2005). Among these sites, Mediterranean lagoons have a particularly large number of introduced macroalgae (Curiel et al., 1998, 2001, a, b; Verlaque, 2001). Indeed, oyster-farming activities make these environments more favorable for macroalgae than they were originally, by supplying ideal suitable substrata in the form of the oysters themselves and cultivation equipment such as ropes, metal structures and plastic net bags (Lamy et al., 1998). Consequently, new macroalgal species appearing in these previously inhospitable environments are likely to have arrived with oysters. Arrival of non-indigenous species can be the result of either a primary introduction directly from a species' native region or a secondary introduction if the species arrives from an area where it has been previously introduced. By some definitions, the term secondary introductions also includes the natural spread of introduced species (Jansson, 2000; Occhipinti-Ambrogi, 2004) but we use it here only for 
human-mediated introductions. Introductions of macroalgae in association with Crassostrea gigas are likely to be primary introductions when imports from North Pacific are involved. In the case of transfers of oysters between European regions, both primary and secondary introductions can occur.

The scientific community is well aware of the importance of shellfish as a vector in the processes of human-mediated introductions of marine organisms (Elton, 1958; Druehl, 1973; Gruet, 1976; Grizel and Héral, 1991; Ribera and Boudouresque, 1995; Wasson et al., 2001; Goulletquer et al., 2002; Ribera-Siguan, 2002; Minchin and Gollasch, 2002; Wolff and Reise, 2002; Weigle et al., 2005). However, direct evidence of the involvement of oyster transfers in such introductions is lacking, especially for macroalgae. Schodduyn (1931) recorded the epiflora and fauna on Ostrea edulis imported from Great Britain to France and cultured some shells in the laboratory, but did not report any exotic species. Korringa (1951) investigated epibiont assemblages on native oysters in the Oosterschelde estuary, but algae were not identified. However, some anecdotal observations of exotic macrolgae on imported oysters have been reported (Gruet et al., 1976; Critchley and Dijkema, 1984; Cecere et al., 2000).

In the present work, we assessed experimentally the risk of transferring macroalgae, particularly non-indigenous species, in association with oysters, from one aquaculture site to another. Transfers of oysters bearing no visible macroalgal organisms were simulated. Crassostrea gigas, involved in many shellfish transfers, is the most important animal aquaculture species in the world (Helm, 2005). Consequently, this species is perfectly suited as a model organism to explore shellfish as a vector of introduction. The experimental donor area was a French Mediterranean lagoon (the Thau lagoon) known to have a large number of established alien macroalgae (Verlaque, 2001). Collection of data involved the detection of non-macroscopic macroalgal stages (i.e. not visible without a microscope) present on the shells after the simulated transfer, by culturing them on the shells until they reached a suitable size for identification. The simulation involved conditions likely to be experienced during surface transport (by road) to most other European oyster farming sites. Therefore, several durations of emersion of the shells were tested, with a maximum of $48 \mathrm{~h}$. Most European destinations can be reached from the experimental donor area within the range of durations tested.

We also tested two elimination, or preventative, treatments (immersion in hot seawater and immersion in brine) in reducing the potential risks of macroalgal transfers with oysters. Some oyster farmers already use these cheap and realistic treatments, mainly to eliminate fouling or boring organisms. The ultimate goal of the study is to improve the current practices involved in shellfish transfer in order to prevent accidental macroalgal introductions.

\section{Methods}

\subsection{Treatment of oyster shells}

Adult Crassostrea gigas reared at various locations in the Thau lagoon, c. $10 \mathrm{~cm}$ in length, were supplied and processed by SODIMER (Loupian, Hérault, France). Processing followed the normal protocol prior to commercial export to other culture areas: (1) Epibionts were manually removed from shells. (2) Oysters were mechanically cleaned in a commercial rotating tubular drum, under a high-pressure seawater spray (S.A. Mulot, La Tremblade, France; http://www.mulot.fr). (3) Oysters were then placed back in the lagoon for two weeks in plastic shellfish net bags in order to decrease stress of the oysters after cleaning and to allow removal of moribund oysters prior to transport. After that period, oysters were brought from the aquaculture facility to the laboratory in insulated containers.

Preliminary trials were made in June 2003 to select the treatment conditions used for further experiments (Table 1). In these trials, the protocol below was followed with the exception that valves had not been labelled and sediments had not been completely removed from them, allowing the proliferation of animals such as amphipods and gastropods in the culture tanks. Consequently many germlings were grazed before reaching a suitable size for identification, and the final protocol therefore involved a sediment removal step.

In the protocol adopted for the experiments, oysters were brought to the laboratory in insulated containers and, after thorough cleansing with seawater to remove sediments, stored briefly in tanks filled with fresh clean seawater. Only seawater from the lagoon, filtered through a $0.2 \mu \mathrm{m}$ pore-size cellulose nitrate membrane (diameter $150 \mathrm{~mm}$; Sartorius A.G., 
Germany) was used for all steps in order to avoid any further settlement of macroalgal propagules (spores or zygotes). Oysters were opened manually; the flesh (including adductor muscles) was completely removed and the two valves were separated. The entire process involved no more than 1 min out of seawater. No macroalgae were visible on the shells at this stage. In each run of experiments (August and October 2003, April 2004), the oyster valves were individually labelled with pencil on the internal side and assigned to different treatments.

These treatments were (Table 1): a control (no emersion, i.e. 0 h), two different emersion periods ( $24 \mathrm{~h}$ and either 6 or $48 \mathrm{~h}$ ) and an "elimination treatment (either heat or brine). For emersion treatments, valves were placed in insulated containers, at a temperature of $c$. $20^{\circ} \mathrm{C}$. The heat treatment was performed on a standard domestic cooker. Shells were immersed in groups of 10 for $3 \mathrm{~s}$ in hot seawater $\left(85^{\circ} \mathrm{C}\right)$. Temperature was checked before each immersion. The protocol is the same as that recommended for professional equipment used for shellfish (S.A. Mulot), designed for larger quantities. For the brine treatment, valves were placed for 30 min in a brine solution following the protocol of Ruellet (2004). Commercial sea salt was added to filtered seawater while stirring. The solution was prepared at least $3 \mathrm{~h}$ before immersion of the shells and kept at a temperature of around $20^{\circ} \mathrm{C}$. The solubility product constant of $\mathrm{NaCl}$ in aqueous solution is 6.136 at $20^{\circ} \mathrm{C}$ (Apelblat and Korin, 1998). Consequently, saturation is reached with $359 \mathrm{~g}$ per litre of freshwater. We added $400 \mathrm{~g}$ of sea salt per litre of seawater in order to speed up the saturation process. After immersion in the solution, shells were left to dry overnight at room temperature, before being placed in culture tanks.

\subsection{Culture of macroalgal stages}

Shells were placed in glass aquarium tanks $(40 \times 15 \times 20 \mathrm{~cm})$. There were 4 replicate tanks per treatment, each with 20 valves per tank, pearly side down, so that each experiment involved 320 valves (4 treatments $\times 4$ replicates $\times 20$ valves). The experimental design using tanks as statistical units reduced the effective number of replicates in comparison to a single tank containing 320 valves. However, beyond the practical issues of maintaining a large experimental tank, the use of separate tanks had the benefit of restricting potential crosscontamination between different treatments. Each tank was filled with 9.6 I filtered seawater from the Thau lagoon and stored briefly in a dark room with a space-cooling system set to its minimum temperature $\left(20^{\circ} \mathrm{C} \pm 3^{\circ} \mathrm{C}\right)$, which suits a wide range of temperate macroalgal species. Bubbling aeration was supplied individually for the 16 tanks in each experiment by 8 Stellar S20 two-output air pumps (Oscar Enterprises Inc., California). Tanks were covered with individual acrylic plates to avoid the loss of water by spray or evaporation. Tanks were placed in two groups, each under 4 Sylvania cool white fluorescent tubes providing a photon irradiance of $150 \mu \mathrm{mol}$ photons $\mathrm{m}^{-2} \mathrm{~s}^{-1}, 16: 8 \mathrm{~h}$ (light: dark). Positions of the different replicates of each treatment were randomized at the start of each culturing period. Culture medium was partially changed at least once every week. Culture conditions were maintained for 40 days, before termination of the experiment.

\subsection{Algal identification and recording}

During the 40-day culturing period following experimental treatments, valves were examined one by one, immersed in a small container, under a stereoscopic microscope, at intervals of around 10 days to avoid missing the presence of short-lived species. Species records were therefore accumulated over the experiment. Macroalgae were sampled with small forceps and identified. Most macroscopic taxa, all belonging to the Chlorophyta, Phaeophyceae and Rhodophyta, were identified to species level. Taxonomic nomenclature is according to the web database of Guiry et al. (2006).

Tubular Ulva (formerly Enteromorpha; Hayden et al., 2003), Cladophora and ectocarpalean ("Ectocarpus-like") individuals could be present in high numbers (several hundred thalli per valve). Only a fraction of these thalli had diagnostic characters. Consequently, they could not be identified to the species level on an individual basis and were treated at a higher taxonomic level (genus or order) for statistical analyses.

As shells were not labelled during the preliminary trial (June 2003), taxa were recorded only by their presence in each tank and not on each valve. These data have not been included in further statistical analyses. 


\subsection{Data analysis}

Availability of macroalgal propagules. As a measure of abundance of individual species, we counted the number of shells within the tank (i.e. ranging from 0 to 20), on which that species (or higher taxon) was present during the culturing period. To give an approximate measure of total propagule density, the scores for each separate species were added together. Usage of the term 'propagule' in this particular context, as in the invasion literature, refers to both reproductive structures (generally spores or zygotes) and microscopic juvenile and adult stages. In the phycological literature propagule is used more restrictively to cover spores, zygotes and related life history stages. The number of taxa per tank was also considered as a measure of the potential macroalgal diversity following the different simulated transport treatments.

Statistical analyses. The influences of treatment and experimental start date were investigated using multivariate comparisons in PRIMER (http://www.pml.ac.uk/primer/index.htm; Clarke and Warwick, 1994) and tested in one- and two-way ANOSIM designs as a measure of the multivariate distance between different sets of replicates (tanks) in macroalgal assemblages. The macroalgal assemblages in each replicate tank were described by the individual abundances (as described earlier) of each species, with differences among tanks estimated using the Bray-Curtis Similarity coefficient.

Univariate statistics were calculated with CCS-Statistica software (Version 5.1, ${ }^{\circledR}$ StatSoft). Response variables analysed were the abundance of different taxa per tank, number of taxa per tank and total propagule density per tank.

\section{Results}

\subsection{Fouling species}

Macroalgae were found in all sets of replicates in all treatments, except for the hot seawater treatment in October 2003. During the initial trial and the three experiments undertaken during this study, 46 macroalgal taxa (57 in total when distinguishing morphotypes belonging to the ectocarpalean, Cladophora and tubular Ulva groups) were found on oyster shells after culture in tanks: 12 in June 2003, 14 in August 2003, 15 in October 2003 and 35 in April 2004 (Table 2). Of 17 macroalgal orders found during this study, 10 belong to the Rhodophyta, 3 to the Phaeophyceae and 4 to the Chlorophyta. In terms of number of taxa, the best-represented orders were Ceramiales, Ectocarpales and Ulvales. The most abundant taxa found during the experiments were tubular Ulva spp. (present on 647 valves, out of 960 possible occurrences), ectocarpalean species (356), Neosiphonia harveyi (235), Dasya sessilis (230), Stylonema alsidii (198) and Ceramium sp. (167).

Following the hot seawater treatment of August 2003, only tubular Ulva were present. No species were recorded from the October 2003 hot water treatment. The treatment in brine reduced macroalgal assemblages to Cladophora spp., tubular Ulva spp., ectocarpalean species, Scytosiphon lomentaria, Porphyra sp. and Stylonema alsidii.

\subsection{Assemblage variation among treatments}

Analyses of similarities among macroalgal assemblages found on oyster valves (per tank) showed a strong temporal effect (Fig. 2). Two-way crossed ANOSIM using the reduced set of treatments common to the three experiments (i.e. $0 \mathrm{~h}$ and $24 \mathrm{~h}$, for August 2003, October 2003 and April 2004) was highly significant for the factor "experiment" (global $R=1, p=0.001$; $\mathrm{R}=1, \mathrm{p} \leq 0.003$ for all pairwise tests) and showed no difference between the two emersion treatments (global $\mathrm{R}=0.073, \mathrm{p}=0.162$ ). One-way ANOSIM using the full range of emersion treatments at each date showed no difference in August 2003 (global $R=0.082, p=0.256$ ) or in October 2003 (global $R=0.022, p=0.591$ ). Slight differences in assemblages among emersion treatments were found in April 2004 (global $R=0.343, p=0.006$ ) with a significant difference between ' 0 h' and ' 48 h' (pairwise $R=0.531, p=0.029$ ).

Macroalgal assemblages following hot seawater and brine treatments were significantly different from emersion treatments (August 2003, 'emersion' vs. 'hot seawater', $R=0.982$, $\mathrm{p}=0.001$; April 2004, 'emersion' vs. 'brine', $\mathrm{R}=0.945, \mathrm{p}=0.001$ ). 
The differences are reflected in univariate comparisons for mean number of taxa and mean total propagule density per tank (Table 3). Bartlett tests showed homogeneity of variance for both variables, in each of the experiments $(p>0.05)$. One-way analyses of variance showed significant differences between treatments in each of the experiments and for both variables (Table 3). Post-hoc tests (Fisher LSD) confirmed that immersion in hot seawater or brine significantly decreased the number and the propagule density of macroalgal taxa per tank when compared to each emersion treatment $(p<0.005)$ across the three experiments.

Two-way ANOVA using the reduced set of treatments in common among dates (' $0 \mathrm{~h}$ ' and ' $24 \mathrm{~h}$ ') did not identify a significant effect of emersion duration but there was a strong temporal effect. Different start dates resulted in significant differences in both the number of taxa and the total propagule density per tank $\left(F_{(2,18)}=28.73, p<0.001\right.$ and $F_{(2,18)}=53.09$, $p<0.001$, respectively). There was no significant interaction between the emersion duration and the timing of the experiment.

An unexpected result occurred when comparing among all available emersion treatments within experiments: longer emersion generally resulted in higher numbers of taxa and more fouling overall (Table 3). Spearman correlation tests were significant for the number of taxa in August $2003(R=0.63, p<0.05)$, in October $2003(R=0.82, p<0.05)$ and for the total propagule density in April $2004(\mathrm{R}=0.62, \mathrm{p}<0.05)$. The same trend was also found at the specific level, when abundance per tank increased with emersion time (Fig. 3). This was the case in August 2003 for Dasya sessilis (Spearman test: $\mathrm{R}=0.78, \mathrm{p}<0.05$ ), in October 2003 for Cladophora sp. (Spearman test: $\mathrm{R}=0.65, \mathrm{p}<0.05)$ and in April 2004 for Antithamnionella spirographidis (Spearman test: $\mathrm{R}=0.86, \mathrm{p}<0.05$ ), Ceramium sp. (Spearman test: $\mathrm{R}=0.90$, $\mathrm{p}<0.05$ ), Lomentaria clavellosa (Spearman test: $\mathrm{R}=0.62, \mathrm{p}<0.05$ ) and Stylonema alsidii (Spearman test: $R=0.61, p<0.05$ ). While there is an element of multiple hypothesis testing across species, the probability of 9 significant correlations from all the possible tests is less than 0.01 (using the Bernoulli formula for multiple tests). In other cases, there was no correlation between the individual abundance per tank and the emersion time.

\section{Discussion}

During this study, the presence of a wide range of seaweeds was revealed on oyster shells grown in laboratory conditions. These algae must already have been present as microscopic stages before culturing, as only filtered seawater was used. Tubular Ulva and ectocarpalean species, most of which are known to be opportunistic and cosmopolitan, were abundant throughout all experiments.

At least 16 out of 57 taxa found during this study are non-indigenous to the experimental donor area, the Thau lagoon (Table 2). A few, such as Polysiphonia fucoides, are native to Atlantic shores but most are introductions from the Indo-Pacific region. Of these, Antithamnionella spirographidis, Asparagopsis armata and Neosiphonia harveyi were probably introduced in Europe before the mid 20th century (Maggs and Hommersand, 1993; Verlaque, 1994; Mclvor et al., 2001); the others arrived later from the same region, presumably in association with oysters (Verlaque, 1994, 2001, 2002; Ribera and Boudouresque, 1995; Ribera-Siguan, 2002; Wallentinus 2002).

Direct evidence for the vector of primary introduction is lacking for all these species. However, their presence in our experiments supports the hypothesis that the vector could have been oyster transfers. The particularly high abundance in some of the experiments of recently introduced species such as Dasya sessilis and Ceramium sp. highlighted the risk of these species spreading and becoming invasive into Europe. The process seems to have been triggered already for Dasya sessilis, first observed in Thau, and now present in the rias of Galicia and the Arcachon basin, both important oyster-farming areas (Peña and Bárbara, 2006; M. Verlaque, unpublished data). Ceramium sp. is morphologically similar to the European species $C$. tenuicorne but is conspecific with an unidentified Australian species of Ceramium (Mclvor, pers. com.). Given the morphological similarity between the Ceramium sp. and $C$. tenuicorne, it is likely that any expansion of this new introduction across European shores will be not easily noticed.

The present study showed an apparently strong temporal effect on macroalgal assemblages found on shells. The total number of taxa in April 2004 was far higher than in other experiments. Macroalgal assemblages cultured in August 2003 and October 2003 were quite species-poor, probably due to the environmental conditions to which oysters were 
exposed prior to the experiment (i.e. during the "resting" period in the lagoon). The summer of 2003 was the period of a major heat wave (Trigo et al., 2005) with negative consequences for the temperate flora of the lagoon. The results from May 2003 are believed to be an underestimate due to the presence of grazers in the microcosms.

However, the temporal effect could hide a spatial effect. Macroalgal composition of the epibiontic assemblages in the study depends strongly on the environmental factors to which oysters were exposed before the experiments. One of these factors is the species of algae present in the immediate surroundings of the oysters during their stay in the lagoon. For example, one reproducing individual of a given species (e.g. Dasya sessilis in October 2003; see Table 2) might have been enough to seed the majority of oysters used in one experiment. Also, the floristic composition in the Thau lagoon shows both temporal and spatial variations (Gerbal and Verlaque, 1995).

During this study, the experimental range of emersion times never had any negative effects on the viability of propagules. Contrary to expectations, in some experiments longer emersions significantly increased the number of taxa, the abundance of some taxa or the total quantity of propagules. Emersion could possibly have a negative effect on some microbial communities, such as bacteria, Cyanobacteria or benthic eukaryotes, and consequently reduce the competition with macroalgal propagules, but evidence is lacking. Schodduyn (1931) likewise mentioned the absence of negative effects of emersion on macroalgae on oysters transiting in parcels for up to four days.

Heat treatment is an efficient way to kill macroalgal propagules such as Undaria pinnatifida zoospores in ballast waters (Mountfort et al., 1999). Immersion of oysters for 20 to 45 seconds in $70{ }^{\circ} \mathrm{C}$ seawater successfully reduced the presence of Polydora worms on Crassostrea gigas (Nel et al., 1996). However, immersion for shorter periods (3 seconds) at higher temperatures $\left(80\right.$ to $85^{\circ} \mathrm{C}$ ) is commonly used by the French oyster industry to remove small oyster spat and other fouling organisms from medium-sized oysters (Dominique Mille, pers. comm.). The present results indicate that this treatment has a lethal effect on nearly all macroalgal settlement. The presence of tubular Ulva spp. after the heat treatment in August could be due to the selection of resistant strains by the exceptional heat wave of summer 2003.

Immersion in saturated brine for a short period is another effective method of control of fouling organisms such as Crepidula fornicata (L.) (Hancock 1969; Franklin 1974). Immersion in brine followed by a prolonged emersion reduced the presence of boring Polydora worms due to the formation of salt crystals on the external surface of the oyster shell (Ruellet, 2004). Brine treatment of oysters is also effective against Sargassum muticum (Lewey, 1976) but not Codium fragile (MacNair and Smith, 1999). In the present study, brine treatment significantly reduced the survival of macroalgal stages and only a few resistant taxa were able to survive (Cladophora spp., tubular Ulva spp., ectocarpalean species, Scytosiphon Iomentaria, Porphyra sp. and Stylonema alsidii).

Immersion in freshwater was not tested during the present study. This method is easy to implement and was used on a large scale on the Japanese imports during the 1970s. Spat and substrata (consisting of Pecten sp. or C. gigas shells) were immersed twice in freshwater, before and just after air freighting, in order to kill some turbellarian predator species (Gruet et al., 1976). This method is also effective against polydorid worms (Dunphy et al., 2005). But, as long immersion durations are required, the protocol is less compatible with oyster-farming activities (Ruellet, 2004). Moreover, this method did not prevent the introduction of other invertebrates and seaweeds in association with Japanese imports (Gruet et al., 1976).

Other preventative methods involve toxic chemicals to remove fouling organisms on oysters for farming purposes (MacKenzie and Shearer, 1959; Ruellet, 2004), or to control invasive species (McEnnulty et al., 2001). However, the use of toxic substances is not suitable for oyster production aimed at human consumption.

The present study showed that most seaweeds are able to settle on oyster shells and to grow when environmental conditions are suitable. Species belonging to 17 macroalgal orders were found during the present study on oysters that originated from only one area. By comparison, only 7 macroalgal orders were found during a survey of commercial boat hull fouling in the same area, involving 23 commercial ships from all over the world (Mineur et al., 2007).

Our experiment involved four simulated transfers of 320 oyster valves each (i.e. 160 oysters, more or less equivalent to $15 \mathrm{~kg}$ ), a very small quantity compared to those transferred every year by European oyster farmers. For example, the $C$. gigas production of the Thau lagoon is wholly dependent on the import, officially from the Atlantic coast, of 
juvenile oysters (205 million in 2001; Girard et al. 2005). Likewise, in France the oysters frequently change rearing basins before their marketing. In 2001, these transfers represented several tens of thousand metric tons of young and adult C. gigas and $2000 \mathrm{t}$ of Ostrea edulis (Girard et al., 2005).

Consequently, oyster transfers have a very great potential as a vector for accidental seaweed introductions. If these transfers occur inside a single biogeographical area with a homogeneous marine flora, the risks of introducing an exotic species are reduced. However, when alien species are present in only some parts of the area involved, oyster transfers are likely to act as a vector of secondary introductions. This is especially true for transfers from the Thau lagoon because it harbors such a large number of introduced species with temperate affinities (Verlaque, 2001). This statement can easily be extrapolated to other oyster farming areas harbouring alien macroalgal flora such as the bay of Arcachon (M. Verlaque, unpublished data), the bay of Carantec in France (Cabioc'h and Magne 1987; Rio and Cabioc'h, 1988), the rias of Galicia in Spain (Bárbara et al., 2005; Peña and Bárbara, 2006) or the Oosterschelde in the Netherlands (Stegenga, 1997, 2004). Moreover, transfers can also lead to cryptogenic introductions of sibling species or exotic strains of native species which are not easily detected (Carlton, 1996).

This study has confirmed the general view that oyster transfers are likely to be an important vector for macroalgal introductions between or within regions. The simulations undertaken in this study showed that oysters visually cleaned of epibionts can still carry a high diversity of viable propagules. This has to be taken into account for future policies, especially for Customs inspections of oysters coming from third countries, and for spat from hatcheries if it has been stored in non-sterilized seawater, even briefly, prior to transport. Routine inclusion of a short heat-treatment step as part of oyster transfer protocols within Europe would contribute greatly to reducing of secondary transfers.

\section{Acknowledgements}

This study was supported by grants from the Programme National sur l'Environnement Côtier (PNEC) "Lagunes Méditerranéennes" and a Fifth Framework Program of the European Community (ALIENS: 'Algal Introductions to European Shores'). We would like to thank Lionel Loubersac, Jean-Claude Sauvagnargues, and the IFREMER Station of Sète for the facilities provided during the work, Jean-Louis Masson (SODIMER) for supplying the oysters, Dominique Mille (CREAA, Poitou Charentes) for providing information about heat treatment and Mme Michèle Boudouresque for bibliographic assistance. We are grateful to CharlesFrançois Boudouresque and Isabelle Arzul for their comments on the manuscript. 


\section{References}

Anonymous, 1980. Activité de l'Institut des Pêches en 1979. Principales actions en matière de cultures marines. Science \& Pêche, Bulletin de l'Institut des Pêches Maritimes 306, 1-39.

Anonymous, 1982. Status (1980) of introductions of non-indigenous marine species to North Atlantic waters. Amendments and additions to Cooperative Research Report, 32 (1972). ICES Cooperative Research Report 116, 1-87.

Anonymous, 1991. Council directive of 28 January 1991 concerning the animal health conditions governing the placing on the market of aquaculture animals and products (91/67/EEC). Official Journal of the European Union L046, 1.

Anonymous, 2003a. Commission decision of 23 May 2003 establishing special conditions for placing on the market of aquaculture animals species considered not susceptible to certain diseases and the products thereof. (2003/390/EC). Official Journal of the European Union L135, 19-24.

Anonymous, 2003b. Commission Decision of 14 November 2003 laying down the animal health conditions and certification requirements for imports of molluscs, their eggs and gametes for further growth, fattening, relaying or human consumption (2003/804/CE). Official Journal of the European Union L302, 22-33.

Anonymous, 2005. Commission Decision of 31 May 2005 amending Annex I to Decision 2003/804/EC laying down the animal health conditions and certification requirements for imports of molluscs, their eggs and gametes for further growth, fattening, relaying or human consumption (2005/409/CE). Official Journal of the European Union L139, 16-18.

Apelblat, A., Korin, E., 1998. The vapour pressures of saturated aqueous solutions of sodium chloride, sodium bromide, sodium nitrate, sodium nitrite, potassium iodate, and rubidium chloride at temperatures from $227 \mathrm{~K}$ to $323 \mathrm{~K}$. Journal of Chemical Thermodynamics 30 , 59-71.

Bárbara, I, Cremades, J., Calvo, S., López-Rodríguez, M.C., Dosil, J., 2005. Checklist of the benthic marine and brackish Galician algae (NW Spain). Anales del Jardín Botánico de Madrid 62: 69-100.

Boudry, P., Heurtebise, S., Collet, B., Cornette, F., Gérard, A., 1998. Differentiation between populations of the Portuguese oyster, Crassostrea angulata (Lamarck) and the Pacific oyster, Crassostrea gigas (Thunberg), revealed by mtDNA RFLP analysis. Journal of Experimental Marine Biology and Ecology 226, 279-291.

Cabioc'h, J., Magne, F., 1987. Première observation du Lomentaria hakodatensis (Lomentariaceae, Rhodophyta) sur les côtes françaises de la Manche (Bretagne Occidentale). Cryptogamie, Algologie 8, 41-48.

Carlton, J.T., 1996. Biological invasions and cryptogenic species. Ecology 77: 1653-1655.

Carlton, J.T., 1996. Pattern, process, and prediction in marine ecology. Biological Conservation 78: 97-106.

Cecere, E., Petrocelli, A., Saracino, O.D., 2000. Undaria pinnatifida (Fucophyceae, Laminariales) spread in the central Mediterranean: its occurrence in the Mar Piccolo of Taranto (Ionian Sea, southern Italy). Cryptogamie, Algologie 21, 305-309.

Clarke, K.R., Warwick, R.R., 1994. Change in marine communities: an approach to statistical analysis and interpretation. Plymouth Marine Laboratory, Natural Environment Research Council, UK.

Critchley, A.T., Dijkema, R., 1984. On the presence of the introduced brown alga Sargassum muticum, attached to commercially imported Ostrea edulis in the S. W. Netherlands. Botanica Marina 27, 211-216.

Curiel, D., Bellemo, G., Marzocchi, M., Scattolin, M., Parisi, G., 1998. Distribution of introduced Japanese macroalgae Undaria pinnatifida, Sargassum muticum (Phaeophyta) and Antithamnion pectinatum (Rhodophyta) in the Lagoon of Venice. Hydrobiologia 385, 17-22.

Curiel,, D., Bellemo, G., Scattolin, M., Marzocchi, M., 2001a. Variazioni della flora bentonica macroalgale nei substrati duri della Laguna di Venezia: Confronto con rilievi del 1938. Lavori, Società Veneziana di Scienze naturali 26, 71-83.

Curiel, D., Bellemo, G., La Rocca, B., Scattolin, M., Marzocchi, M., 2001b. Note su specie algali nuove per la laguna di Venezia. Lavori, Società Veneziana di Scienze naturali 26, 101-102.

Druehl, L.D., 1973. Marine transplantations. Science 179, 12. 
Dunphy, B.J., Wells, R.M.G., Jeffs, A.G., 2005. Polydorid infestation in the flat oyster, Tiostrea chilensis: hyposaline treatment for an aquaculture candidate. Aquaculture International 13, 351-358.

Elton, C.S., 1958. The ecology of invasions by animals and plants. Methuen, London.

Franklin, A., 1974. The destruction of the oyster pest Crepidula fornicata by brine-dipping. Fisheries Research Technical Report 8. Fisheries laboratory, Ministry of Agriculture, Fisheries and Food, Lowestoft, UK.

Gerbal, M., Verlaque, M., 1995. Macrophytobenthos de substrat meuble de l'étang de Thau (France, Méditerranée) et facteurs environnementaux associés. Oceanologica Acta 18, 557-571.

Girard, S., Pérez Agúndez, J.A., Miossec, L., Czerwinski, N., 2005. Recensement de la conchyliculture 2001. Agreste Cahiers 1, 1-87.

Goulletquer, P., Bachelet, G., Sauriau, P.G., Noël, P., 2002. Open Atlantic coast of Europe a century of introduced species into French waters, in: Leppäkoski, E., Gollasch, S., Olenin, S. (Eds.), Invasive aquatic species of Europe - Distribution, impacts and management. Kluwer Academic Publishers, Dordrecht, the Netherlands, pp. 276-290.

Goulletquer, P., Le Moine, O., 2002. Shellfish farming and Coastal Zone Management (CZM) development in the Marennes-Oléron Bay and Charentais Sounds (Charente Maritime, France): A review of recent developments. Aquaculture International 10, 507-525.

Grizel, H., Héral, M., 1991. Introduction into France of the Japanese oyster (Crassostrea gigas). Journal du Conseil International pour l'Exploration de la Mer 47, 399-403.

Grosholz, E.D., Ruiz, G.M., Dean, C.A., Shirley, K.A., Maron, J.L., Connors, P.G., 2000. The impacts of a nonindigenous marine predator in a California bay. Ecology 81: 1206-1224.

Gruet, Y., 1976. Présence de l'algue japonaise Sargassum muticum (Yendo) Fensholt sur la côte française de Normandie. Bulletin de la Société des Sciences Naturelles de l'Ouest de la France 74, 101-104.

Gruet, Y., Héral, M., Robert, J.M., 1976. Premières observations sur l'introduction de la faune associée au naissain d'huîtres japonaises Crassostrea gigas (Thunberg), importé sur la côte atlantique française. Cahiers de Biologie Marine 17, 173-184.

Guiry, M.D., Rindi, F., Guiry, G.M., 2006. AlgaeBase version 4.0. http://www.algaebase.org/. Accessed March 31 2006. National University of Ireland, Galway, Ireland.

Gurevitch, J., Padilla, D.K., 2004. Are invasive species a major cause of extinctions? Trends in Ecology and Evolution 19: 470-474.

Hancock, D.A., 1969. Oyster pests and their control. Laboratory Leaflet New Series 19. Ministry of Agriculture Fisheries and Food, Burnham on Crouch, UK.

Hayden, H.S., Blomster, J., Maggs, C.A., Silva, P.C., Stanhope, M.J., Waaland, J. R., 2003. Linnaeus was right all along: Ulva and Enteromorpha are not distinct genera. European Journal of Phycology 38, 277-294.

Héral, M., 1990. Traditional oyster culture in France, in: Barnabé, G. (Ed.), Aquaculture. Ellis Horwood, London, pp. 342-387.

Helm, M.M., 2005. Cultured Aquatic Species Information Programme - Crassostrea gigas. Cultured Aquatic Species Fact Sheets. http://www.fao.org/figis/servlet/static?dom=culturespecies\&xml=Crassostrea gigas.xml/. Accessed October 5 2006. FAO Inland Water Resources and Aquaculture Service (FIRI), Rome.

Jansson, K., 2000. The marine environment, in: Weidema, I.R. (Ed.), Introduced Species in the Nordic Countries. Nord 13, Nordic Council of Ministers, Copenhagen, pp. 43-86.

Kolar, C.S., Lodge, D.M., 2001. Progress in invasion biology: predicting invaders. Trends in Ecology and Evolution 16: 199-204.

Korringa, P., 1951. The shell of Ostrea edulis as a habitat. Archives Néerlandaises de Zoologie 10, 32-152.

Lamy, N., Lauret, M., Guelorget, O., 1998. Structure et mise en place des peuplements macrophytiques de substrats durs d'une table conchylicole de l'étang de Thau (Hérault, France). Vie Milieu, 48, 171-181.

Le Borgne, M., Gras, M.P., Comps, M., Carruesco, G., Razet, D., 1973. Observations sur la reproduction des huîtres dans la Seudre (Bassin de Marennes-Oléron) en 1972. ICES CM 1973/K, 16.

Lewey, S.A., 1976. Studies on the brown alga Sargassum muticum (Yendo) Fensholt in Britain. MPhil thesis, Portsmouth Polytechnic. 
Lockwood, J.L., Cassey, P., Blackburn, T., 2005. The role of propagule pressure in explaining species invasions. Trends in Ecology and Evolution 20: 223-228.

MacKenzie, C.L., Shearer, L.W., 1959. Chemical control of Polydora websteri and other annelids inhabiting oyster shells. Proceedings of the National Shellfisheries Association 50, 105-111.

MacNair, N., Smith, M., 1999. Investigations into treatments to control fouling organisms affecting oyster production. Annual Meeting of the National Shellfisheries Association, Halifax, NS (Canada), April 18-22, 1999. Abstracts. Journal of Shellfish Research 18, 331.

Maggs, C.A., Hommersand, M.H., 1993. Seaweeds of the British Isles. Volume 1. Rhodophyta. Part 3A. Ceramiales. The National History Museum, London, UK.

McEnnulty, F.R., Jones, T.E., Bax, N.J. 2001. The Wed-Based Rapid Response Toolbox. $<$ http://crimp.marine.csiro.au/NIMPIS/controls.htm>.

Mclvor, L., Maggs, C.A., Provan, J., Stanhope, M.J., 2001. rbcL sequences reveal multiple cryptic introductions of the Japanese red alga Polysiphonia harveyi. Molecular Ecology 10, 911-919.

Minchin, D., 1996. Management of the introduction and transfer of marine molluscs. Aquatic Conservation: Marine and Freshwater Ecosystems 6, 229-244.

Minchin, D., Gollasch, S., 2002. Vectors - How exotics get around, in: Leppäkoski, E., Gollasch, S., Olenin, S. (Eds.), Invasive aquatic species of Europe - Distribution, impacts and management. Kluwer Academic Publishers, Dordrecht, the Netherlands, pp. 183-192.

Mineur, F., Johnson, M.P., Maggs, C.A., Stegenga, H., 2007. Hull fouling on commercial ships as a vector of macroalgal introduction. Marine Biology DOI 10.1007/s00227-0060567-y

Mountfort, D.O., Hay, C., Taylor, M., Buchanan, S., Gibbs, W., 1999. Heat treatment of ships' ballast water: development and application of a model based on laboratory studies. Journal of Marine Environmental Engineering 5, 193-206.

Nel, R., Coetzee, P.S., Van Niekerk, G., 1996. The evaluation of two treatments to reduce mud worm (Polydora hoplura Claparède) infestation in commercially reared oysters (Crassostrea gigas Thunberg). Aquaculture 141, 31-39.

Occhipinti-Ambrogi, A., Galil, B.S., 2004. A uniform terminology on bioinvasions: a chimera or an operative tool ? Marine Pollution Bulletin 49, 688-694.

O'Foighil, D., Gaffny, P.M., Hilbish, T.J., 1997. The Portuguese oyster Crassostrea angulata is of Asian origin. Journal of Shellfish Research 16, 329.

Peña, V., Bárbara, I., 2006. Dasya sessilis (Ceramiales, Rhodophyta), a new alien species for the European Atlantic coasts. Anales del Jardín Botánico de Madrid (in press).

Pérez, R., Lee, J.Y., Juge, C., 1981. Observations sur la biologie de l'algue japonaise Undaria pinnatifida (Harvey) Suringar introduite accidentellement dans l'Etang de Thau. Science \& Pêche, Bulletin de l'Institut des Pêches Maritimes 315, 1- 12.

Piazzi, L., Cinelli, F., 2003. Evaluation of benthic macroalgal invasion in a harbour area of the western Mediterranean Sea. European Journal of Phycology 38: 223-231.

Ribera, M.A., Boudouresque, C.F., 1995. Introduced marine plants, with special reference to macroalgae: mechanisms and impact, in: Round, F.E., Chapman, D.J. (Eds.), Progress in Phycological Research, Volume 11. Biopress Limited, Bristol, UK, pp. 217-268.

Ribera-Siguan, M.A., 2002. Review of non-native marine plants in the Mediterranean Sea, in: Leppäkoski, E., Gollasch, S., Olenin, S. (Eds.), Invasive aquatic species of Europe Distribution, impacts and management. Kluwer Academic Publishers, Dordrecht, the Netherlands, pp. 291-310.

Rio, A., Cabioc'h, 1988. Apparition du Caulacanthus ustulatus (Rhodophyta, Gigartinales) dans la Manche occidentale. Cryptogamie, Algologie $9: 231-234$.

Riouall, R., 1985. Sur la présence dans l'étang de Thau (Hérault, France) de Sphaerotrichia divaricata (C. Agardh) Kylin et Chorda filum (L.) Stackhouse. Botanica Marina 27, 83-86.

Robert, J., Morancais, M., Pradier, E., Mouget, J., Tremblin, G., 2002. Extraction and quantitative analysis of the blue-green pigment 'marennine' synthesized by the diatom Haslea ostrearia. Journal of Applied Phycology 14, 299-305.

Robert, R., Gerard, A., 1999. Bivalve hatchery technology: the current situation for the Pacific oyster Crassostrea gigas and the scallop Pecten maximus in France. Aquatic Living Resources 12, 121-130.

Ruellet, T., 2004. Infestation des coquilles d'huîtres Crassostrea gigas par les polydores en Basse-Normandie : recommandations et mise au point d'un traitement pour réduire cette 
nuisance. PhD thesis, Université Caen/lfremer, Plouzané, France.< http://www. ifremer.fr/docelec/doc/2004/these-162.pdf>

Schodduyn, R., 1931. Observations sur la flore et la faune des coquilles des huîtres. Bulletin de l'Institut Océanographique de Monaco 568, 1- 20.

Stegenga, H., 1997. Een nieuwe Japanse invase - vooral een systematisch probleem. Het Zeepaard 57, 109-113.

Stegenga, H., 2004. Lomentaria hakodatensis, een "nieuwe" invasiesoort in Zeeland. Het Zeepaard 64: 145-148.

Strong, J.A., Dring, M.J., Maggs, C.A., 2006. Colonisation and modification of soft substratum habitats by the invasive macroalga Sargassum muticum. Marine Ecology Progress Series 321: 87-97.

Trigo, R.M., García-Herrera, R., Díaz, J., Trigo, I.F., Valente, M.A., 2005. How exceptional was the early August 2003 heatwave in France? Geophysical Research Letters 32, L10701.

Turpin, V., Robert, J., Goulletquer, P., Masse, G., Rosa, P., 2001. Oyster greening by outdoor mass culture of the diatom Haslea ostrearia Simonsen in enriched seawater. Aquaculture Research 32, 801-809.

Utting, S.D., Spencer, B.E., 1992. Introductions of marine bivalve molluscs into the United Kingdom for commercial culture - case histories. ICES Marine Science Symposia 194, 84-91.

Verlaque, M., 1981. Contribution à la flore des algues marines de Méditerranée : espèces nouvelles pour la Méditerranée Occidentale. Botanica Marina 24, 559-568.

Verlaque, M., 1994. Inventaire des plantes marines introduites en Méditerranée : origines et répercussions sur l'environnement et les activités humaines. Oceanologica Acta 17, 1-23.

Verlaque, M., 2001. Checklist of the macroalgae of Thau Lagoon (Hérault, France): a hot spot of marine species introduction in Europe. Oceanologica Acta 24, 29-49.

Verlaque, M., 2002. Morphology and reproduction of Dasya sessilis (Ceramiales, Rhodophyta) - an introduced Asiatic species thriving in Thau Lagoon (France, Mediterranean Sea). Phycologia 41, 612-618.

Verlaque, M., Belsher, T., Deslous-Paoli, J.M., 2002. Morphology and reproduction of Asiatic Ulva pertusa (Ulvales, Chlorophyta) in Thau Lagoon (France, Mediterranean Sea). Cryptogamie, Algologie 23, 301-310.

Verlaque, M., Brannock, P.M., Komatsu, T., Villalard-Bohnsack, M., Marston, M., 2005. The genus Grateloupia C. Agardh (Halymeniaceae, Rhodophyta) in the Thau Lagoon (France, Mediterranean): a case study of marine plurispecific introductions. Phycologia 44, 477496.

Wallentinus, I., 2002. Introduced marine algae and vascular plants in European aquatic environments, in: Leppäkoski, E., Gollasch, S., Olenin, S. (Eds.), Invasive aquatic species of Europe - Distribution, impacts and management. Kluwer Academic Publishers, Dordrecht, the Netherlands, pp. 27-52.

Wasson, K., Zabin, C.J., Bedinger, L., Diaz, M.C., Pearse, J.S., 2001. Biological invasions of estuaries without international shipping: the importance of intraregional transport. Biological Conservation 102: 143-153.

Weigle, S.M., Smith, L.D., Carlton, J.T., Pederson, J., 2005. Assessing the risk of introducing exotic species via the live marine species trade. Conservation Biology 19, 213-223.

Wolff, W.J., Reise, K., 2002. Oyster imports as a vector for the introduction of alien species into northern and western European coastal waters, in: Leppäkoski, E., Gollasch, S., Olenin, S. (Eds.), Invasive aquatic species of Europe - Distribution, impacts and management. Kluwer Academic Publishers, Dordrecht, the Netherlands, pp. 193-205. 


\section{Spat production (from in situ stocks or hatcheries): \\ e.g. W. France (Arcachon Bay, Marennes-Oléron Bay), UK (Guernsey)}

Imports from native area and other third countries:

e.g. Canada (Pacific Coast), Japan (between 1971 and 1977)

\section{Sanitary procedures (prior} to marketing): no specific localities
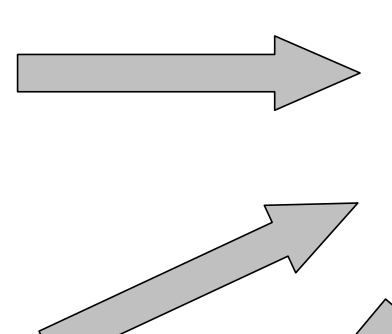

Growth of livestock:

e.g. Thau Lagoon, Brittany, Republic of Ireland, Denmark, Spain, Portugal, Russia (Black Sea), New Caledonia

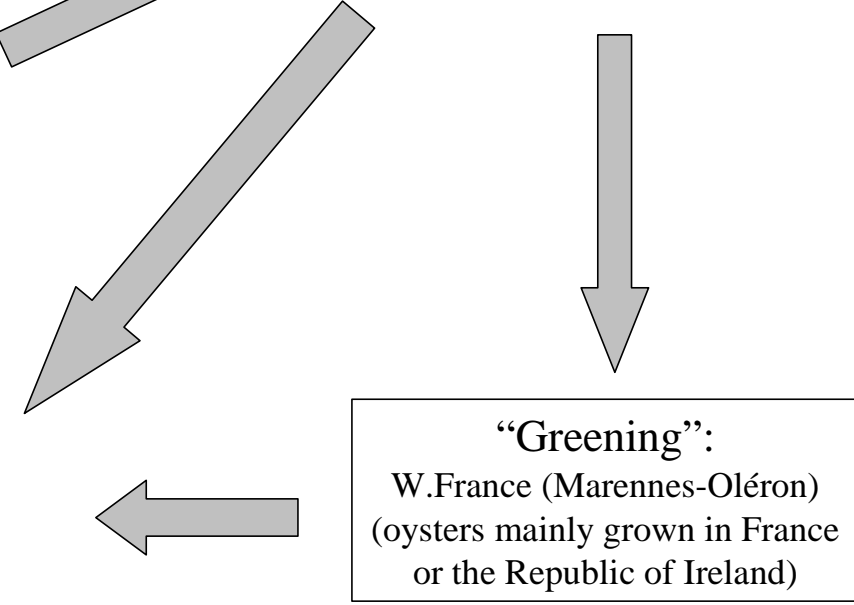

Fig. 1. Flow chart indicating examples of transfers of Crassostrea gigas involved in French and European mariculture production. All arrows indicate potential transfers of livestock. List of sites is based on information in the text and on personal observations. Due to market sensitivities about the source of oysters it is difficult to obtain exact figures for the scale of these transfers. 


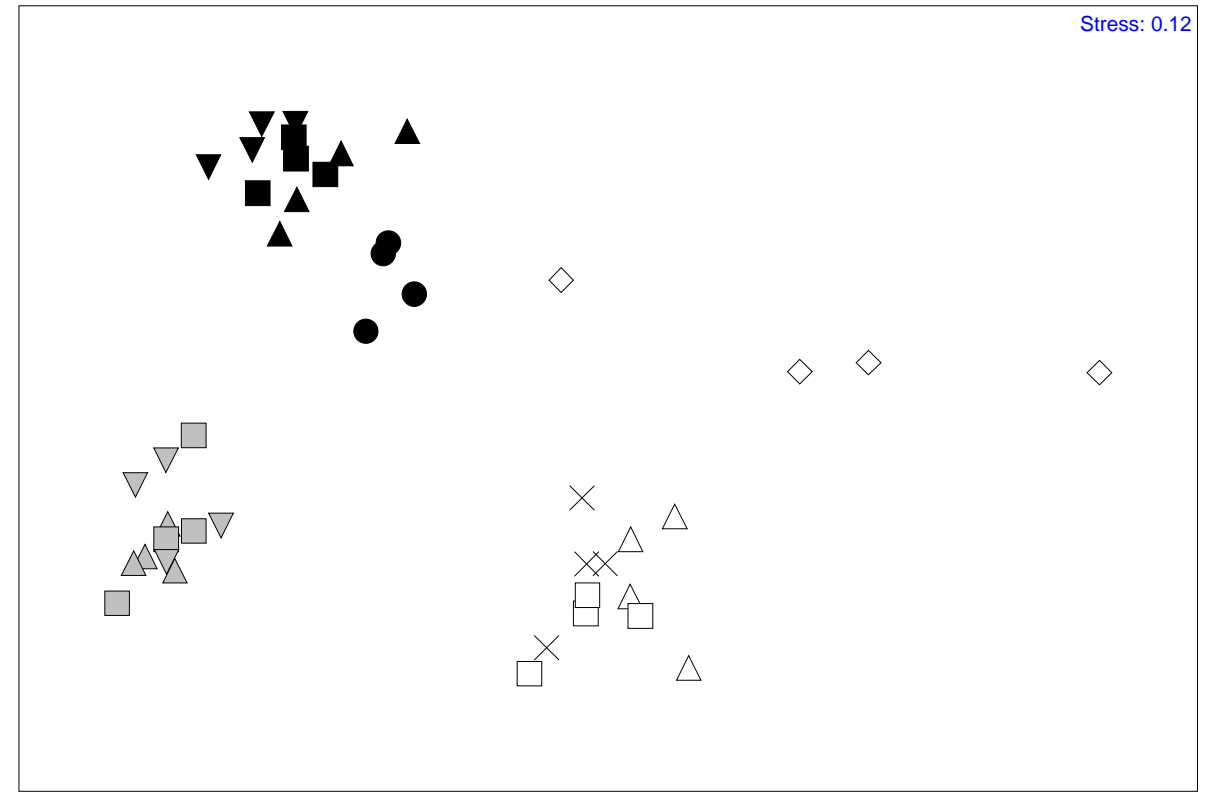

Fig. 2. Similarities among macroalgal assemblages on oyster valves in each single tank, for all experiments, following ordination by nonparametric multidimensional scaling (MDS). August $2003(\Delta=0 \mathrm{~h}$ emersion; $x=6 \mathrm{~h}$ emersion; $\square=24 \mathrm{~h}$ emersion; $\diamond=$ hot seawater $)$, October 2003 ( $\boldsymbol{\Delta}=0 \mathrm{~h}$ emersion; $\boldsymbol{\|}=24 \mathrm{~h}$ emersion; $\boldsymbol{\nabla}=48 \mathrm{~h}$ emersion), April 2004 ( $\boldsymbol{\Delta}=0$ $\mathrm{h}$ emersion; $\mathbf{-}=24 \mathrm{~h}$ emersion; $\boldsymbol{\nabla}=48 \mathrm{~h}$ emersion; $\bullet=$ brine). The hot seawater treatment in October 2003 is not shown as no taxa were recorded. 

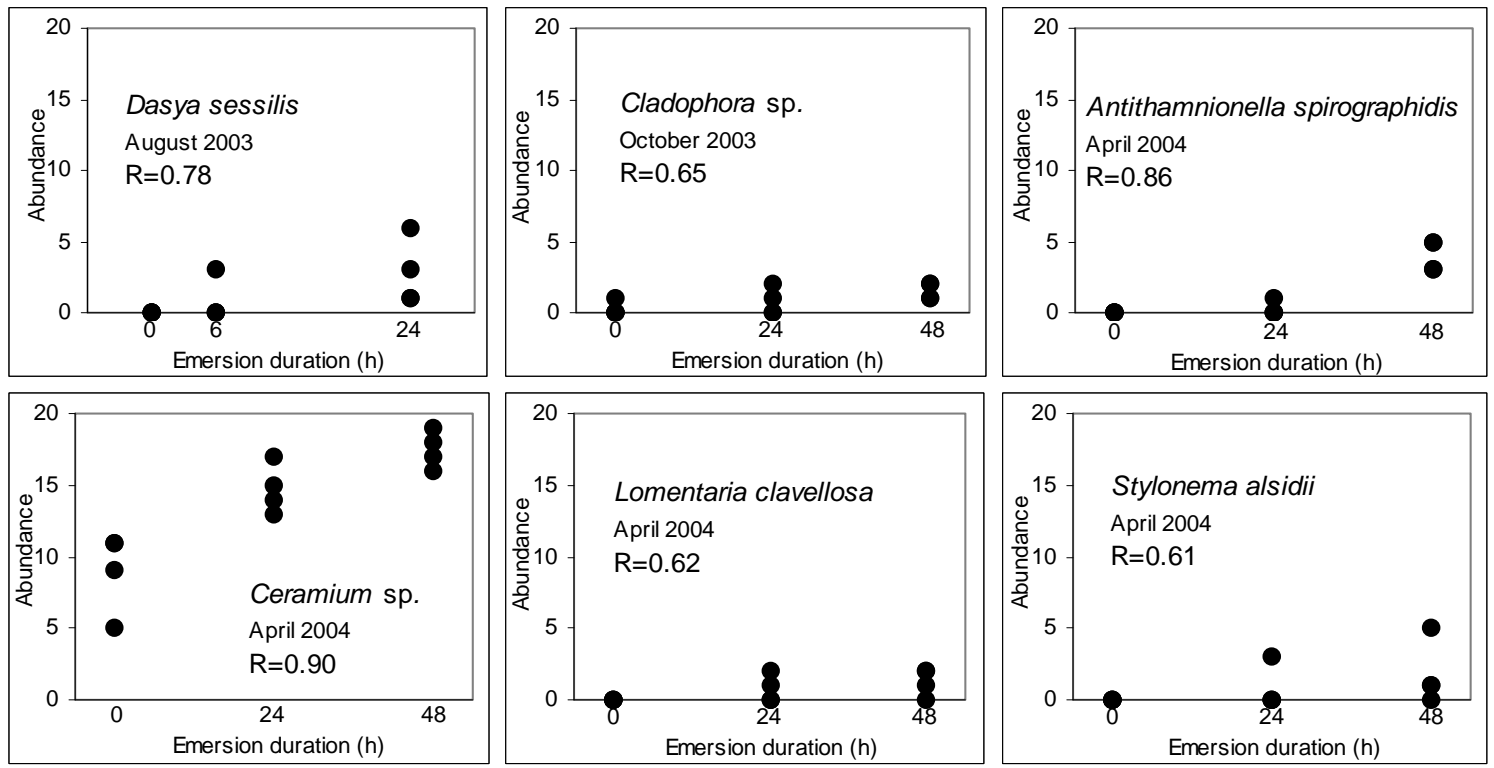

Fig. 3. Macroalgal abundance (number of colonized valves) per tank in relation to emersion duration. Spearman correlation coefficients are significant $(p<0.05)$ for the six macroalgal species shown. 
Table 1. Treatments applied to the oyster shells during the study.

\begin{tabular}{cccccccc}
\hline & Control & \multicolumn{3}{c}{ Emersion treatments } & \multicolumn{2}{c}{ Elimination treatments } \\
& $0 \mathrm{~h}$ & $6 \mathrm{~h}$ & $24 \mathrm{~h}$ & $48 \mathrm{~h}$ & Heat & Brine \\
\hline June 2003 (preliminary) & $\mathrm{X}$ & $\mathrm{X}$ & $\mathrm{X}$ & - & $\mathrm{X}$ & - \\
August 2003 & $\mathrm{X}$ & $\mathrm{X}$ & $\mathrm{X}$ & - & $\mathrm{X}$ & - \\
October 2003 & $\mathrm{X}$ & - & $\mathrm{X}$ & $\mathrm{X}$ & $\mathrm{X}$ & - \\
April 2004 & $\mathrm{X}$ & - & $\mathrm{X}$ & $\mathrm{X}$ & - & $\mathrm{X}$ \\
\hline
\end{tabular}


Table 2. List of macroalgal species found on oyster shells during the different experiments. Numbers refer to the total number of valves bearing the taxon (maximum value is 320 per experiment); + = presence; - = absence; * = macroalgae introduced into the Thau lagoon, according to Verlaque (2001) and Verlaque (unpublished).

\section{RHODOPHYCEAE}

Bangiales

Bonnemaisoniales

Ceramiales

Colaconematales

Corallinales

Erythropeltidales

Goniotrichales

Halymeniales

Rhodymeniales

Stylonematales

PHAEOPHYCEAE

Cutleriales

Ectocarpales

Fucales

CHLOROPHYCEAE

Bryopsidales

Cladophorales

Ulotrichales

Ulvales
Porphyra sp.

Asparagopsis armata Harvey ("Falkenbergia rufolanosa" phase) *

Aglaothamnion tenuissimum (Bonnemaison) Feldmann-

Mazoyer

Antithamnion cruciatum (C. Agardh) Nägeli

Antithamnionella spirographidis (Schiffner) E.M.

Wollaston *

Callithamnion corymbosum (J.E. Smith) Lyngbye

Ceramium cimbricum H.E. Petersen

Ceramium secundatum Lyngbye

Ceramium sp. *

Chondria dasyphylla (Woodward) C. Agardh

Dasya sessilis Yamada *

Dasysiphonia sp. *

(=Heterosiphonia japonica Yendo)

Laurencia okamurae Yamada *

Neosiphonia harveyi (J. Bailey) M.-S. Kim, H.-G. Choi,

Guiry \& G.W. Saunders *

Nitophyllum stellato-corticatum Okamura *

Osmundea truncata (Kützing) K.W. Nam \& Maggs

Polysiphonia atlantica Kapraun \& J.N. Norris *

Polysiphonia denudata (Dillwyn) Greville ex Harvey

Polysiphonia elongata (Hudson) Sprengel

Polysiphonia fucoides (Hudson) Greville *

Polysiphonia stricta (Dillwyn) Greville

Pterosiphonia tanakae S. Uwai \& M. Masuda *

Pterothamnion crispum (Ducluzeau) Nägeli

Sphondylothamnion multifidum (Hudson) Nägeli

Colaconema daviesii (Dillwyn) Stegenga

Hydrolithon farinosum (J.V. Lamouroux) D. Penrose \&

Y.M. Chamberlain

Erythrotrichia investiens (Zanardini) Bornet

Chroodactylon ornatum (C. Agardh) Basson

Grateloupia sp. *

Lomentaria clavellosa (Turner) Gaillon

Lomentaria hakodatensis Yendo *

Stylonema alsidii (Zanardini) K.M. Drew

June August October April

$2003-2003 \quad 2003 \quad 2004$

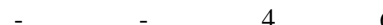

$207 \quad 9$

- $\quad$ -

$\begin{array}{lll}166 & 22 & 47\end{array}$

Cutleria multifida (Turner) Greville

Colpomenia peregrina Sauvageau *

Ectocarpalean species (including "Acinetospora crinita"

phase, Ectocarpus siliculosus (Dillwyn) Lyngbye,

Feldmannia irregularis (Kützing) G. Hamel, Hincksia mitchelliae (Harvey) P.C. Silva, H. sandriana (Zanardini)

P.C. Silva, Kuckuckia spinosa (Kützing) Kornmann,

Pylaiella littoralis (Linnaeus) Kjellman *)

Scytosiphon lomentaria (Lyngbye) Link

Stictyosiphon adriaticus Kützing

Cystoseira sp.

Sargassum muticum (Yendo) Fensholt *

Cladophora spp. (including C. dalmatica Kützing, C. cf. laetevirens (Dillwyn) Kützing and C. liniformis Kützing)

Ulothrix flacca (Dillwyn) Thuret

Ulothrix subflaccida Wille

Blidingia marginata (J. Agardh) P. Dangeard ex Bliding Ulva spp. (foliose)

Ulva spp. (tubular) (including U. clathrata (Roth) C.

Agardh, U. compressa Linnaeus, U. flexuosa Wulfen and

U. prolifera O.F. Müller)
1

1

17

1

27

27

1

17

28

-

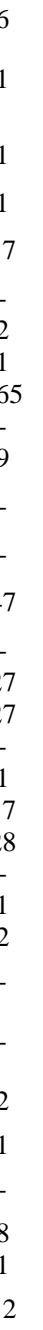

87


Table 3. Number of macroalgal taxa and total propagule density per tank for each experiment and each treatment (mean \pm confidence interval; $n=4$ ) and ANOVA results for comparison between treatments in each experiment.

\begin{tabular}{|c|c|c|c|c|c|}
\hline Experiment & Treatment & \multicolumn{2}{|c|}{ Number of taxa per tank } & \multicolumn{2}{|c|}{$\begin{array}{l}\text { Total propagule density } \\
\text { per tank }\end{array}$} \\
\hline \multirow{4}{*}{ August 2003} & Oh & $4.8( \pm 1.2)$ & \multirow{4}{*}{$\begin{array}{c}\mathrm{F}_{3,12}=14.55 \\
\mathrm{p}<0.001\end{array}$} & $26.3( \pm 4.0)$ & \multirow{4}{*}{$\begin{array}{c}\mathrm{F}_{3,12}=14.65 \\
\mathrm{p}<0.001\end{array}$} \\
\hline & $6 \mathrm{~h}$ & $6.3( \pm 2.0)$ & & $30.3( \pm 3.2)$ & \\
\hline & $24 \mathrm{~h}$ & $7.0( \pm 1.4)$ & & $31.5( \pm 5.5)$ & \\
\hline & Hot seawater & $1.0( \pm 0.0)$ & & $10.0( \pm 6.8)$ & \\
\hline \multirow{4}{*}{ October 2003} & Oh & $7.5( \pm 1.3)$ & \multirow{4}{*}{$\begin{array}{c}\mathrm{F}_{3,12}=147.67 \\
\mathrm{p}<0.001\end{array}$} & $60.5( \pm 7.2)$ & \multirow{4}{*}{$\begin{array}{c}\mathrm{F}_{3,12}=132.1 \\
9 \\
\mathrm{p}<0.001\end{array}$} \\
\hline & $24 \mathrm{~h}$ & $8.3( \pm 0.5)$ & & $61.0( \pm 2.1)$ & \\
\hline & $48 \mathrm{~h}$ & $10.5( \pm 0.6)$ & & $67.5( \pm 7.8)$ & \\
\hline & Hot seawater & $0.0( \pm 0.0)$ & & $0.0( \pm 0.0)$ & \\
\hline \multirow{4}{*}{ April 2004} & Oh & $12.8( \pm 2.3)$ & \multirow{4}{*}{$\begin{array}{c}\mathrm{F}_{3,12}=17.40 \\
\mathrm{p}<0.001\end{array}$} & $63.3( \pm 13.0)$ & \multirow{4}{*}{$\begin{array}{c}\mathrm{F}_{3,12}=19.89 \\
\mathrm{p}<0.001\end{array}$} \\
\hline & $24 \mathrm{~h}$ & $12.5( \pm 2.9)$ & & $74.5( \pm 10.9)$ & \\
\hline & $48 \mathrm{~h}$ & $14.8( \pm 2.7)$ & & $79.8( \pm 4.9)$ & \\
\hline & Brine & $3.5( \pm 1.0)$ & & $34.3( \pm 3.0)$ & \\
\hline
\end{tabular}

